\title{
Regimen Used to Treat Malignant Soft Tissue Neoplasm
}

National Cancer Institute

\section{Source}

National Cancer Institute. Regimen Used to Treat Malignant Soft Tissue Neoplasm. NCI

Thesaurus. Code C159462.

Any regimen that can be used for the treatment of malignant soft tissue neoplasm. 